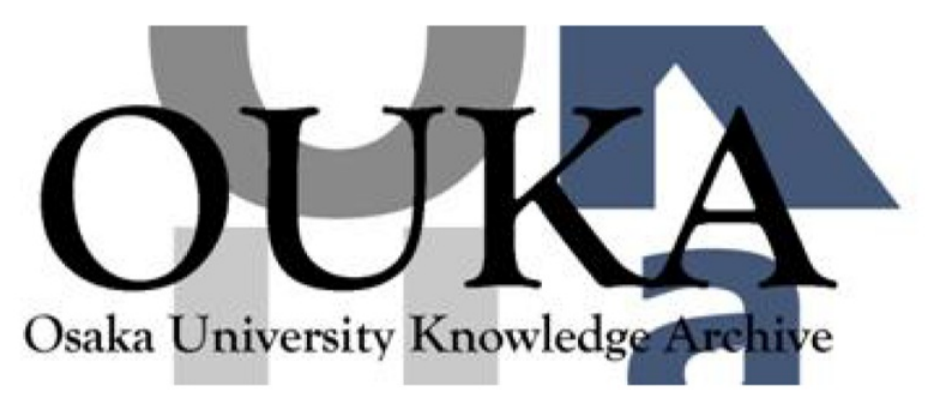

\begin{tabular}{|c|l|}
\hline Title & $\begin{array}{l}\text { First X-ray Structure Determination of a } \\
\text { Bismuthio Ylide : 4, 4-Dimethy L-2,6-dioxo-1- } \\
\text { tripheny lbismuthiocyc lohexanide }\end{array}$ \\
\hline Author(s) & $\begin{array}{l}\text { Yasui, Masanori; Kikuchi, Takeshi; Iwasaki, } \\
\text { Fujiko et al. }\end{array}$ \\
\hline Citation & $\begin{array}{l}\text { JOURNAL OF THE CHEMICAL SOCIETY-PERKIN } \\
\text { TRANSACTIONS 1. 12 p. 3367-p.3368 }\end{array}$ \\
\hline Issue Date & $1990-12$ \\
\hline oaire:version VoR \\
\hline URL & https://hdl. handle. net/11094/3458 \\
\hline rights & \\
\hline Note & \\
\hline
\end{tabular}

Osaka University Knowledge Archive : OUKA

https://ir. Library. osaka-u. ac. jp/

Osaka University 


\title{
First X-Ray Structure Determination of a Bismuthio Ylide: 4,4-Dimethyl-2,6- dioxo-1-triphenylbismuthiocyclohexanide
}

\author{
Masanori Yasui, ,a Takeshi Kikuchi,‘ Fujiko Iwasaki," Hitomi Suzuki, ${ }^{b, *}$ Toshihiro Murafuji ${ }^{b}$ and \\ Takuji Ogawac.* \\ - Department of Applied Physics and Chemistry, The University of Electro-Communications, Chofugaoka, \\ Chofu, Tokyo 182, Japan \\ ${ }^{\circ}$ Department of Chemistry, Faculty of Science, Kyoto University, Kyoto, Kitashirakawa, 606, Japan \\ 'Department of Chemistry, Faculty of Science, Ehime University, Matsuyama, 790, Japan
}

The first $X$-ray structure analysis of a bismuthio ylide has been made for 4,4-dimethyl-2,6-dioxo-1 triphenylbismuthiocyclohexanide. The $B i-C_{y l i d e}$ bond is $2.16 \AA$, only $0.05-0.06 \AA$ shorter than the $\mathrm{Bi}-\mathrm{C}_{\mathrm{Ph}}$ single bond, revealing that the $\mathrm{Bi}-\mathrm{C}_{\text {vide }}$ bond is polarized as $\mathrm{C}^{-}-\mathrm{Bi}^{+}$or $\mathrm{O}^{-}-\mathrm{C}=\mathrm{C}_{-}-\mathrm{Bi}^{+}$ with little double bond character between the $\mathrm{Bi}$ and the ylidic carbon.

Bismuthio ylides are the heaviest and least understood of all the carbon-hetero atom ylides. Although several papers ${ }^{1-6}$ have appeared on them since 1967 when the first was reported, ${ }^{7}$ no definite structural proofs for their identity has hitherto been described. Bismuthio ylides react with numerous compounds in a variety of different ways depending on the substrates involved and the reaction conditions employed. ${ }^{8-10}$ This behaviour stands in marked contrast to that of the ylides derived from lighter elements ( $\mathrm{P}, \mathrm{As}$, and $\mathrm{Sb}$ ) of the same group.

The bismuthio ylide 1 described by Lloyd ${ }^{7}$ was a deep blue, high-melting solid (m.p. $195^{\circ} \mathrm{C}$; decomp.) which readily decomposed in solution, while the ylide $\mathbf{2 b}$ obtained by Barton ${ }^{2}$ was a gummy substance. Recently, the ylides $\mathbf{2 b}$ and $\mathbf{3}$ were obtained pure as pale yellow crystals, ${ }^{6}$ the former crystallizing from benzene-hexane as single crystals suitable for $\mathrm{X}$-ray structural elucidation.

As shown in Fig. $1,{ }^{11}$ three phenyl groups of the bismuthio ylide have regular bond angles and distances. The dioxocyclohexane ring, which has pseudo mirror symmetry and lies through two methine groups, $C(19)$ and $C(22)$, is almost planar (root-mean-square deviation of $0.021 \AA$ ), except for the two methyl groups on $\mathrm{C}(22)$. The bismuth atom lies on this plane with a deviation of $0.036 \AA$. The most interesting features of

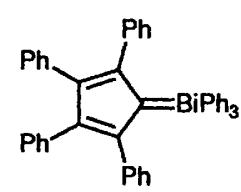

1<smiles>[R]C1([R])CC(=O)C(=Cc2ccccc2)C(=O)C1</smiles>

2a; $R=H$ 2b; $\mathrm{R}=\mathrm{Me}$<smiles>CC1(C)OC(=O)C(=[Pb]c2ccccc2)C(=O)O1</smiles>

3 this compound are the carbon-bismuth bonds. The bismuth atom has a distorted tetragonal configuration with bond angles $\mathrm{C}_{\mathrm{Ph}}-\mathrm{Bi}-\mathrm{C}_{\mathrm{Ph}}=101.6(4)-103.1(4)^{\circ}$ and $\mathrm{C}(19)-\mathrm{Bi}-\mathrm{C}_{\mathrm{Ph}}=$ 111.8(4)-119.6(4) ${ }^{\circ}$. The bond length of $\mathrm{Bi}-\mathrm{C}(19), 2.16 \AA$, is slightly shorter than the single bond length of $\mathrm{Bi}-\mathrm{C}_{\mathrm{Ph}} 2.21(1)-$ 2.22(1) $\AA$. The lengths of the $\mathrm{Bi}-\mathrm{C}_{\mathrm{Ph}}$ bond obtained here are comparable with those of triphenylbismuth, $2.21-2.25 \AA . .^{12}$ These facts suggest that the ylide bond has a large degree of ionic character as $\mathrm{Bi}^{+}-\mathrm{C}^{-}$or $\mathrm{Bi}^{+}-\mathrm{C}=\mathrm{C}-\mathrm{O}^{-}$, in accordance with expectation that the vacant $6 \mathrm{~d}$ orbitals of bismuth would not effectively overlap the $2 \mathrm{p}$-orbitals of the carbanionic moiety.

An important proposal made by Lloyd in 1988 concerning the structure and reactivity of carbonyl or sulphonyl substituted arsonium and stibonium ylides, ${ }^{4}$ was that interaction between 
Table 1. Selected bond lengths and atomic distances of the bismuthio ylide

\begin{tabular}{ll}
\hline & Length $(\AA)$ \\
\hline $\mathrm{Bi}-\mathrm{C}^{-}$ & $2.156(11)$ \\
$\mathrm{Bi}-\mathrm{C}^{\mathrm{Ph}}$ & 2.210 \\
$\mathrm{Bi} \cdots \mathrm{O}(1)$ & $3.352(2)$ \\
$\mathrm{Bi} \cdots \mathrm{O}(2)$ & $3.019(4)$ \\
$\mathrm{C}-\mathrm{C}[=\mathrm{O}(1)]$ & $1.412(16)$ \\
$\mathrm{C}-\mathrm{C}[=\mathrm{O}(2)]$ & $1.401(18)$ \\
$\mathrm{C}=\mathrm{O}(1)$ & $1.261(15)$ \\
$\mathrm{C}=\mathrm{O}(2)$ & $1.236(19)$ \\
\hline
\end{tabular}

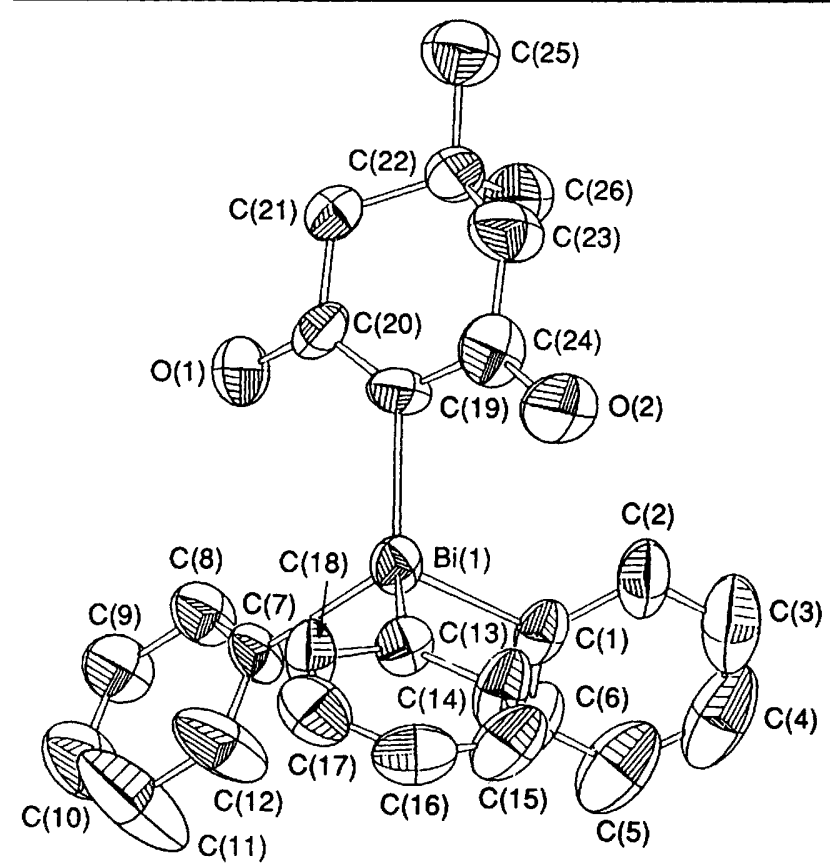

Fig. 1. An ORTEP ${ }^{11}$ drawing of $2 b$ with atomic numbering. Nonhydrogen atoms are depicted as $50 \%$ probability ellipsoids.

the heteroatom and substitutent oxygen atoms would favour the canonical form A with a non-symmetrical crystallographic structure; such compounds would be characterized by low reactivity. Such a non-symmetrical structure was found for the bismuthio ylide described here; thus one $\mathrm{Bi}-\mathrm{O}$ distance is significantly less than the other (Table 1). Although the observed lowfield ${ }^{13} \mathrm{C}$ NMR signal of the ylidic carbon $(\delta 113)$ is consistent with the canonical form $\mathbf{A}$, some doubt remains about its contribution to the structure of the bismuthio ylide; if the canonical form $A$ is substantial, the length of $C=O(1)$ bond, being more remote from the metallic atom, should be shorter than that of another $\mathrm{C}=\mathrm{O}(2)$ group. This applies well to the arsonium and stibonium ylides, but the opposite result was observed for the bismuthio ylide; the $\mathrm{C}=\mathrm{O}(1)$ bond is longer than the $\mathrm{C}=\mathrm{O}(2)$. Probably, the non-symmetrical structures of these ylides are the consequence of both electrostatic and steric factors, and do not always reflect the electron density distributions directly. ${ }^{13}$

Lloyd and his co-workers reported the isolation of 1-triphenylbismuthio-2,6-dioxocyclohexanide (2a) from the coppercatalysed reaction of a diazo compound with triphenyl-

* For details see 'Instructions for Authors (1990),' J. Chem. Soc., Perkin Trans. 1, 1990, Issue 1.<smiles>[R]C1([R])CC(=O)C([Y16]([H])([H])[O-])=C(O)C1</smiles>

A<smiles>[R]C1CC(=O)C([R])C(=O)CC1=O</smiles>

$\mathbf{B}$ bismuthine. ${ }^{4}$ It was claimed to be insoluble in common solvents and to lack reactivity toward 2,4-dinitrobenzaldehyde even under prolonged heating in benzene. However, in our hands, both bismuthio ylides $2 \mathrm{a}^{10}$ and $\mathbf{2 b}$, the identity of the latter now being confirmed unambiguously by $\mathrm{X}$-ray analysis, are quite soluble in most organic solvents and react smoothly with a variety of compounds including the less reactive 4-methoxybenzaldehyde. $^{8-10}$ Thus, the khaki product described by Lloyd as the ylide $2 \mathbf{a}$ is highly likely to be some polymeric substances derived from decomposition of the initially formed ylide.

\section{References}

1 B. H. Freeman, D. Lloyd and M. I. C. Singer, Tetrahedron, 1972, 28, 343.

2 D. H. R. Barton, J. Blazejewski, B. Charpiot, J. Finet, W. B. Motherwell, M. T. B. Papoula and S. P. Stanforth, J. Chem. Soc., Perkin Trans. 1, 1985, 2667.

3 D. Lloyd, I. Gosney and R. A. Ormiston, Chem. Soc. Rev., 1987, 16, 45.

4 G. Ferguson, C. Glidewell, I. Gosney, D. Lloyd, S. Metcalfe and H. Lumbroso, J. Chem. Soc., Perkin Trans. 2, 1988, 1829.

5 C. Glidewell, D. Lloyd and S. Metcalfe, Synthesis, 1988, 319.

6 H. Suzuki, T. Murafuji and T. Ogawa, Chem. Lett., 1988, 847.

7 D. Lloyd and M. I. Singer, J. Chem. Soc., Chem. Commun., 1967, 1042.

8 T. Ogawa, T. Murafuji and Suzuki, Chem. Lett., 1988, 849.

9 T. Ogawa, T. Murafuji, K. Iwata and H. Suzuki, Chem. Lett., 1989, 325.

10 T. Ogawa, T. Murafuji and H. Suzuki, J. Chem. Soc., Chem. Commun., 1989, 1749.

11 C. K. Johnson, ORTEP II, Report ORNL-5138, Oak Ridge National Laboratory, Tennessee (1976). Crystal structure data of $\mathbf{2 b}$ : monoclinic, space group $P 2, / n, a=15.564(2), b=14.520(2), c=$ $10.160(1) \AA, \beta=90.16(2)^{\circ}, V=2296.0(5) \AA^{3}, T=297 \mathrm{~K}, Z=4$, $D_{\mathrm{x}}=1.674 \mathrm{Mg} \mathrm{m}^{-3}, D_{\mathrm{m}}=1.67 \mathrm{Mg} \mathrm{m}^{-3}$ (fiotation), $\mu(\mathrm{Mo}-\mathrm{K} \alpha, \lambda=$ $0.71069 \AA)=7.67 \mathrm{~mm}^{-1}, \quad F(000)=1120$. Intensity data were collected on a Rigaku AFC4 four-circle diffractometer in the range $2<2 \theta<55^{\circ}$. Data were corrected for Lorentz-polarization and absorption effects. The structure was solved from conventional heavy-atom method using SHELXS $86^{14}$ program and refined by block-diagonal least-squares using UNICSIII ${ }^{15}$ to $R=0.056$, $w R=0.050$ for 3647 reflections. Neutral atomic scattering factors from International Tables for X-ray Crystallography. ${ }^{16}$ Atomic coordinates, bond lengths and bond angles, and thermal parameters are available on request from the Cambridge Crystallographic Data Centre. ${ }^{*}$ They have also been deposited at the Fachinformationszentrum Energie, Physik, Mathematik GmbH, D-7514 EggensteinLeopoldshafen 2 (FRG).

12 D. M. Hawley and G. Ferguson, J. Chem. Soc. A, 1968, 2059.

13 As a possibility, the non-symmetrical structure may be a result of orbital symmetry demand: M. V. Veidis, G. H. Schreiber, T. E. Gough and G. J. Palenik, J. Am. Chem. Soc., 1969, 91, 1859.

14 G. M. Sheldrick, SHELXS86, Program for crystal structure determination, University of Gottingen, Federal Republic of Germany, 1986.

15 T. Sakurai and K. Kobayashi, Rikagaku Kenkyusho Hokoku, 1979, $55,69$.

16 International Tables for X-ray Crystallography, Vol. IV, Kynoch Press, Birmingham, 1974, vol. 4 (present distributor, D. Reidel, Dordrecht). 